\title{
Glyphosate-Resistant Giant Ragweed (Ambrosia trifida L.): 2,4-D Dose Response and Control with Postemergence Herbicides in Soybean
}

\author{
Joanna Follings $^{1}$, Nader Soltani ${ }^{1 *}$, Darren E. Robinson ${ }^{1}$, François J. Tardif ${ }^{2}$, Mark B. Lawton ${ }^{3}$, \\ Peter H. Sikkema ${ }^{1}$ \\ ${ }^{1}$ University of Guelph Ridgetown Campus, Ridgetown, Canada; ${ }^{2}$ University of Guelph, Guelph, Canada; ${ }^{3}$ Monsanto Canada, Guelph, \\ Canada. \\ Email: ${ }^{*}$ soltanin@uoguelph.ca
}

Received June $25^{\text {th }}, 2013$; revised July $25^{\text {th }}, 2013$; accepted August $15^{\text {th }}, 2013$

Copyright (C) 2013 Joanna Follings et al. This is an open access article distributed under the Creative Commons Attribution License, which permits unrestricted use, distribution, and reproduction in any medium, provided the original work is properly cited.

\begin{abstract}
Glyphosate resistant giant ragweed is an increasing problem in glyphosate resistant cropping systems in southwestern Ontario. The postemergence herbicides registered for use in soybean in Ontario do not provide consistent control of glyphosate resistant giant ragweed. There is limited research on the lowest effective rate of 2,4-D for the control of glyphosate resistant giant ragweed. Consequently, the objectives of this study were a) to determine the efficacy of herbicides applied postemergence for the control of glyphosate resistant giant ragweed in glyphosate resistant soybean, and b) to determine the lowest effective rate of 2,4-D for the control of glyphosate-resistant giant ragweed. Ten postemergence herbicide combinations and seven rates of 2,4-D were evaluated in field studies conducted in 2011 and 2012 at six locations confirmed with glyphosate-resistant giant ragweed. The post emergence herbicides evaluated did not provide acceptable/consistent control. Of the herbicides evaluated, glyphosate plus cloransulam-methyl provided $26 \%$ to $70 \%$ control 8 WAA of glyphosate resistant giant ragweed, which was the best of the herbicides combinations evaluated. The doses of 2,4-D required to reduce giant ragweed shoot dry weight by 50, 80 and 95\% were 142,310 and $1048 \mathrm{~g}$ a.e. $\mathrm{ha}^{-1}$, respectively
\end{abstract}

Keywords: Glyphosate Resistance; Multiple Herbicide-Resistant Crops; Preplant Herbicides; Postemergence Herbicides

\section{Introduction}

Glyphosate is the most widely used postemergence, nonselective herbicide in the world [1] and is used in row crops, orchards, fallow lands and pastures [2]. Since the introduction of glyphosate resistant soybean in 1996, there has been a rapid increase in the use of glyphosate resistant crops [3]. In large soybean growing countries such as Argentina and the United States, more than $90 \%$ of soybeans grown are glyphosate resistant [3,4]. The use of glyphosate resistant crops has changed weed management practices causing intense selection pressure for glyphosate resistant weeds [5]. There is a widespread glyphosate resistance in weed species around the world. The first glyphosate resistant weed reported was a population of rigid ryegrass (Lolium rigidum L. Gaud) in Australia

"Corresponding author. in 1996 [6]. Since then, additional glyphosate resistant weeds were reported. Currently there are 24 weed species resistant to glyphosate worldwide [7].

Giant ragweed (Ambrosia trifida L.) is an erect broadleaf weed that can be found in southern areas of Manitoba, Ontario, Quebec, New Brunswick, Nova Scotia and Prince Edward Island in Canada [8]. In Ontario it is commonly found in crop production fields in the southwestern part of the province [9]. Giant ragweed is difficult to control due to its long emergence period. Giant ragweed seedlings begin to emerge in early March [10] and continue to emerge until late July [11]. Historically, growers in Ontario would control this problematic weed with glyphosate; however, in 2008 giant ragweed was confirmed to be resistant to glyphosate [12].

Glyphosate resistant giant ragweed is an increasing problem in glyphosate resistant cropping systems in On- 
tario. As of 2010 there were 48 locations confirmed with glyphosate resistant giant ragweed in Ontario (Vink et. al., 2012). There are few herbicides applied postemergence that provide acceptable control of glyphosate resistant giant ragweed control in soybean. Vink et al. [13] reported that glyphosate $\left(900 \mathrm{~g}\right.$ a.e. $\left.\mathrm{ha}^{-1}\right)$ plus cloransulam-methyl $\left(17.5 \mathrm{~g} \mathrm{a.i} \mathrm{h}^{-1}\right)$ provided $80 \%$ to $81 \%$ control of glyphosate resistant giant ragweed 8 weeks after application (WAA). Research is required to identify additional postemergence herbicides for the control of glyphosate resistant giant ragweed in soybean. The first objective of this study was to determine the efficacy of all the currently registered postemergence broadleaf herbicides registered for use in Ontario in soybean.

2,4-D is a herbicide commonly used for the control of broadleaf weeds and has been reported to control giant ragweed with one application [8]. Similarly Vink et al. [14] reported that glyphosate $\left(900 \mathrm{~g}\right.$ a.e. $\left.\mathrm{ha}^{-1}\right)$ plus 2,4-D $\left(500 \mathrm{~g}\right.$ a.e. $\left.\mathrm{ha}^{-1}\right)$ applied as a preplant burndown provided 97 to $99 \%$ control of glyphosate resistant giant ragweed. Research is required to identify the lowest effective rate of 2,4-D for the control of glyphosate resistant giant ragweed. The second objective of this study was to determine the lowest effective rate of 2,4-D tank mixed with glyphosate and applied as a preplant burndown for the control of glyphosate-resistant giant ragweed in soybean.

\section{Materials and Methods}

Field studies were conducted in 2011 and 2012 at six locations for the postemergence broadleaf herbicide experiment and five locations for the 2,4-D dose response experiment with confirmed glyphosate resistant giant ragweed. The field sites were located near Windsor (L2 and L5), La Salle (L1, L4 and L6) and Amherstburg (L3), Ontario. The first series of experiments evaluated the effectiveness of postemergence broadleaf herbicides. The second series of experiments, evaluated the biologically effective rate of 2,4-D, is referred to as "dose response". Soil texture, soil organic matter content, soil $\mathrm{pH}$, soybean cultivar, seeding date, seeding rate, row spacing, herbicide application date and giant ragweed height are presented in Table 1.

Experiments were set up in a randomized complete block design with four replications. Each plot was $8 \mathrm{~m}$ long and $2.5 \mathrm{~m}$ wide. Herbicides in the postemergence study included glyphosate ( $900 \mathrm{~g}$ a.e. ha $\left.{ }^{-1}\right)$ applied alone, and acifluorfen $\left(600 \mathrm{~g}\right.$ a.i. ha $\left.{ }^{-1}\right)$, fomesafen $(240 \mathrm{~g}$ a.i. $\left.\mathrm{ha}^{-1}\right)+$ Turbocharge $(0.50 \% \mathrm{v} / \mathrm{v})$, bentazon $(1080 \mathrm{~g}$ a.i. $\left.\mathrm{ha}^{-1}\right)$, thifensulfuron-methyl $\left(6 \mathrm{~g}\right.$ a.i. ha $\left.\mathrm{h}^{-1}\right)+$ Agral 90 $(0.010 \% \mathrm{v} / \mathrm{v})+$ UAN $28 \%\left(8.0 \mathrm{~L} \cdot \mathrm{ha}^{-1}\right)$, chlorimuronethyl $\left(9 \mathrm{~g}\right.$ a.i. $\left.\mathrm{ha}^{-1}\right)+$ Agral $90(0.20 \% \mathrm{v} / \mathrm{v})+$ UAN $28 \%$ $\left(2.0 \mathrm{~L}^{\circ} \mathrm{ha}^{-1}\right)$, cloransulam-methyl $\left(17.5 \mathrm{~g}\right.$ a.i. $\left.\mathrm{ha}^{-1}\right)+$ Agral $90(0.25 \% \mathrm{v} / \mathrm{v})+$ UAN $28 \%(2.5 \% \mathrm{v} / \mathrm{v})$, imazethapyr $\left(100 \mathrm{~g}\right.$ a.i. $\left.\mathrm{ha}^{-1}\right)+$ Agral $90(0.25 \% \mathrm{v} / \mathrm{v})+$ UAN $28 \%\left(2.0 \mathrm{~L} \cdot \mathrm{ha}^{-1}\right)$, or imazethapyr $\left(75 \mathrm{~g}\right.$ a.i. $\left.\mathrm{ha}^{-1}\right)$ plus bentazon $\left(840 \mathrm{~g}\right.$ a.i. ha $\left.{ }^{-1}\right)+$ UAN $28 \%\left(2.0 \mathrm{~L}^{-h^{-1}}\right)$ applied with glyphosate $\left(900 \mathrm{~g}\right.$ a.e. $\left.\mathrm{ha}^{-1}\right)$ and glyphosate/ fomesafen $\left(1200 \mathrm{~g}\right.$ a.i. $\left.\mathrm{ha}^{-1}\right)$. The herbicide rates used were the maximum labeled rate registered for use in Ontario. The dose response experiment evaluated glyphosate $\left(900\right.$ a.e. $\left.\mathrm{ha}^{-1}\right)$ applied with $2,4-\mathrm{D}$ at $31.25,62.5,125$, $250,500,1000$ or 2000 g a.e. ha ${ }^{-1}$. A weedy and weedfree check was included in each experiment. All weedfree check plots were maintained with 2,4-D ester $(500 \mathrm{~g}$ a.e. $\left.\mathrm{ha}^{-1}\right)$ and glyphosate $\left(900 \mathrm{~g}\right.$ a.e. $\left.\mathrm{ha}^{-1}\right)$ applied preplant (PP) and subsequent hand hoeing as required.

Herbicide treatments were applied with a $\mathrm{CO}_{2}$-ressurized backpack sprayer equipped with ULD 120 - 02 nozzles (Hypro, New Brighton, MN) calibrated to deliver $200 \mathrm{~L}^{-h^{-1}}$ of water at $210 \mathrm{kPa}$. Herbicide treatments were applied with a 1.5 meter boom with four nozzles spaced $50 \mathrm{~cm}$ apart over the centre of the plot. Herbicide treatments were applied when giant ragweed reached 15 $\mathrm{cm}$ in height (Table 1).

Table 1. Location and soil characteristics, soybean cultivar, seeding date, soybean population, herbicide application date, and giant ragweed height at time of application for a post herbicide and 2,4-D dose experiments conducted in Ontario in 2011 and 2012.

\begin{tabular}{|c|c|c|c|c|c|c|c|c|c|}
\hline Location & Year & $\begin{array}{c}\text { Soil } \\
\text { texture }\end{array}$ & $\begin{array}{l}\text { Soil } \\
\text { OM }\end{array}$ & $\begin{array}{c}\text { Soil } \\
\text { pH }\end{array}$ & $\begin{array}{l}\text { Soybean } \\
\text { cultivar }\end{array}$ & $\begin{array}{l}\text { Seeding } \\
\text { date }\end{array}$ & $\begin{array}{c}\text { Soybean } \\
\text { population }\end{array}$ & $\begin{array}{c}\text { Herbicide } \\
\text { application date }\end{array}$ & $\begin{array}{c}\text { Giant ragweed } \\
\text { height }\end{array}$ \\
\hline & & & $(\%)$ & & & & $\left(\right.$ seeds $\left.\cdot h^{-1}\right)$ & & $(\mathrm{cm})$ \\
\hline 1-LaSalle & 2011 & Loam & 2.6 & 7.5 & Dekalb $31-10$ & June 13 & 467,029 & May 21 & $0-7$ \\
\hline 2-Windsor & 2011 & Loam & 2.8 & 6.9 & Pioneer 92 Y 80 & June 15 & 420,079 & June 2 & $0-12$ \\
\hline 3-Amherstburg & 2012 & Clay loam & 3.7 & 7.9 & Pioneer 92 Y 53 & May 22 & 568,100 & May 1 & $0-7$ \\
\hline 4-LaSalle & 2012 & Loam & 3.1 & 7.3 & Dekalb $21-11$ & May 16 & 444,780 & May 8 & $0-10$ \\
\hline 5-Windsor & 2012 & Clay loam & 4.6 & 6.6 & Pioneer $93 \mathrm{Y} 05$ & June 8 & 432,250 & May 8 & $0-10$ \\
\hline 6-LaSalle & 2012 & Loam & 3.1 & 7.3 & Dekalb $21-11$ & May 16 & 444,780 & May 8 & $0-11$ \\
\hline
\end{tabular}


Weed control was rated visually 1, 2, 4 and 8 WAA on a scale of $0 \%$ to $100 \%$, where $0 \%$ was no control of giant ragweed compared to the weedy check and $100 \%$ was complete control of giant ragweed. At each control rating giant ragweed height and density (plants per two $0.25 \mathrm{~m}^{2}$ quadrats) were recorded. At 4 WAA, giant ragweed density and biomass was determined in each plot by counting giant ragweed plants in two $0.25 \mathrm{~m}^{2}$ quadrats. Giant ragweed plants were cut off at the soil surface from the two quadrats, placed in bags, dried at $60^{\circ} \mathrm{C}$ to a constant moisture content and the dry weights were recorded. Soybean injury was rated 1, 2, 4 and 8 WAA. Soybean injury was rated visually on a scale of $0 \%$ to $100 \%$, where $0 \%$ was no soybean injury and $100 \%$ was soybean death. At crop maturity, soybeans were hand harvested from $2 \mathrm{~m}$ of row from each plot at all locations. Soybeans were threshed in a stationary thresher and the weight and moisture were recorded. Yields were adjusted to $13.5 \%$ moisture.

\subsection{Statistical Analysis}

\subsubsection{Postemergence Herbicides}

An analysis of variance was conducted on all data using the PROC MIXED procedure in SAS (Ver. 9.2, SAS Institute Inc., Cary, NC). Variances were separated into the random effects of location (year and location), replication (at each location) and location by treatment. Herbicide treatment was considered the fixed effect. The significance of the random effects (location, replication and location by treatment) and their interaction with fixed effects was tested using the Z-test of the variance estimate. The significance of the fixed effects was tested using the F-test. Significant location by treatment interactions were found for all variables; therefore, locations were analyzed according to their interaction and presented accordingly. To ensure the assumptions (errors are independent, homogenous and normally distributed) of the variance analysis were met; residual plots were examined. Data were tested for normality using the Shapiro-Wilk statistic as generated by the UNIVARIATE procedure in SAS. If necessary, a transformation of the data (natural log, square root or arcsine square root) was applied and chosen based on the highest Shapiro-Wilk statistic generated. Control data 1 WAA were arcsine square root transformed at L2, L4, L5 and L6 and data at L1 and L3 were $\log$ transformed. Control data 2 WAA were arcsine square root transformed at L1, L2, L5 and L6 and data at L3 and L4 were log transformed. Control data 4 WAA were arcsine transformed at L1 and L2 and data at L3, L4, L5 and L6 were log transformed. Control data 8 WAA were square root transformed at L1, L2 and L3 and data at L4, L5, and L6 were log transformed. All giant ragweed shoot dry weight data was square root transformed. Soybean yield data were square root transformed at L1 and L2 and data at L3, L4, L5 and L6 were arcsine square root transformed. The means between treatments were separated using Fisher's protected LSD at $\mathrm{P}<0.05$.

\subsubsection{Field Dose Response}

An analysis of variance was conducted on all data using the PROC MIXED procedure in SAS (Ver. 9.2, SAS Institute Inc., Cary, NC). Variances were separated into the random effects of location (year and location), replication (at each location) and location by treatment. Herbicide treatment was considered the fixed effect. The significance of the random effects (location, replication and location by treatment) and their interaction with fixed effects was tested using the Z-test of the variance estimate. The significance of the fixed effects was tested using the F-test. Significant location by treatment interactions were found for all variables; therefore, locations were analyzed according to their interaction and presented accordingly. To ensure the assumptions (errors are independent, homogenous and normally distributed) of the variance analysis were met; residual plots were examined. Data were tested for normality using the Shapiro-Wilk statistic as generated by the UNIVARIATE procedure in SAS. If necessary, a transformation of the data (natural log, square root or arcsine square root) was applied and chosen based on the highest Shapiro-Wilk statistic generated. Control data 1 WAA were arcsine square root transformed at L1, L2, L3 and L5 and data at L4 was log transformed. Control data 2 WAA were arcsine square root transformed at L1, L2, L3, and L5 and data at L4 were not transformed. Control data 4 WAA were arcsine square root transformed at L1, L4, L3 and L5 and data at L2 was square root transformed. Control data 8 WAA were arcsine square root transformed at all locations. Giant ragweed shoot dry weight was presented as a percent of the weedy control and was log transformed. Soybean yield was presented as a percent of the weed-free control and was not transformed.

A non-linear regression analysis was conducted on all data using the PROC NLIN procedure in SAS (Ver. 9.2, SAS Institute Inc., Cary, NC). A sigmoidal log-logistic curve was used:

$$
\mathrm{Y}=\mathrm{C}+(\mathrm{D}-\mathrm{C}) /\left\{1+\exp \left[\mathrm{B}\left(\ln (\text { dose })-\ln \left(\mathrm{I}_{50}\right)\right)\right]\right\}
$$

where $\mathrm{Y}$ is percent giant ragweed control or percent soybean yield, $\mathrm{C}$ is the lower limit, $\mathrm{D}$ is the upper limit, $\mathrm{B}$ is the slope, and $\mathrm{I} 50$ is the dose where there is a $50 \%$ response [15]. The effective dose (ED) of 2,4-D was also calculated using this equation. Where possible, the ED50, 
ED80 and ED95 were calculated and represent the dose required to achieve $50 \%, 80 \%$, and $95 \%$ control of glyphosate resistant giant ragweed compared to the weedfree control. The ED50, ED80 and ED95 also represent $50 \%, 80 \%$, and $95 \%$ of the soybean yield compared to the weed-free control. For giant ragweed shoot dry weight, the ED50, ED80, and ED95 represent the dose needed to reduced giant ragweed shoot dry weight by $50 \%, 80 \%$ and $95 \%$.

\section{Results and Discussion}

\subsection{Postemergence Herbicides}

Control of glyphosate resistant giant ragweed with postemergence herbicides is extremely difficult as no herbicide consistently provided greater than $75 \%$ control at 1 WAA (Table 2). At 1 WAA, control data at L4, L5 and L6 could be combined and L1, L2 and L3 were analyzed separately (Table 2). Control with glyphosate ranged from $30 \%$ to $56 \%$ confirming the resistance status of the sites. Glyphosate plus fomesafen as a tank mix and glyphosate/fomesafen as a premix were the most effective treatments providing $75 \%$ to $88 \%$ and $69 \%$ to $83 \%$ control, respectively. The highest level of control 1 WAA with the addition of acifluorfen or bentazon to glyphosate was $81 \%$ and $82 \%$ control, respectively (Table 2). Glyphosate plus thifensulfuron, chlorimuron-ethyl, cloran- sulam-methyl, imazethapyr, or imazethapyr plus bentazon provided less than $80 \%$ control.

At 2 WAA, L1 and L2, L5 and L6 could be combined while L3 and L4 were analyzed separately (Table 3). Two weeks after application, all treatments had a level of control that was declining compared to the 1 WAA assessment. Glyphosate provided less than $40 \%$ control of glyphosate resistant giant ragweed across all locations, while the addition of fomesafen provided $52 \%$ to $74 \%$ control which is similar to the findings of Vink et al. [13] who reported $50 \%$ to $86 \%$ control with glyphosate plus fomesafen applied at the same rate. Glyphosate/fomesafen or glyphosate plus acifluorfen, thifensulfuron, chlorimuron-ethyl, cloransulam-methyl, bentazon, imazethapyr, or imazethapyr plus bentazon provided less than $76 \%$ control across all locations (Table 3).

At 4 WAA data could be combined and analyzed in groups L1 and L2 and L3, L4, L5 and L6 (Table 4). Glyphosate provided $23 \%$ to $32 \%$ control, while glyphosate plus imazethapyr provided $46 \%$ to $82 \%$ control. This is similar to the findings of Vink et al. [13] who reported $69 \%$ to $82 \%$ control with glyphosate plus imazethapyr applied at $900 \mathrm{~g}$ a.e. ha ${ }^{-1}+100 \mathrm{~g}$ a.i. ha ${ }^{-1}$. Surprisingly, glyphosate plus cloransulam-methyl provided $56 \%$ to $74 \%$ control 4 WAA opposite to what was observed before with this herbicide combination providing $88 \%$ to 92\% control [13]. Cloransulam-methyl POST is espe-

Table 2. Percent control of glyphosate resistant giant ragweed 1 WAA with herbicides applied post emergence.

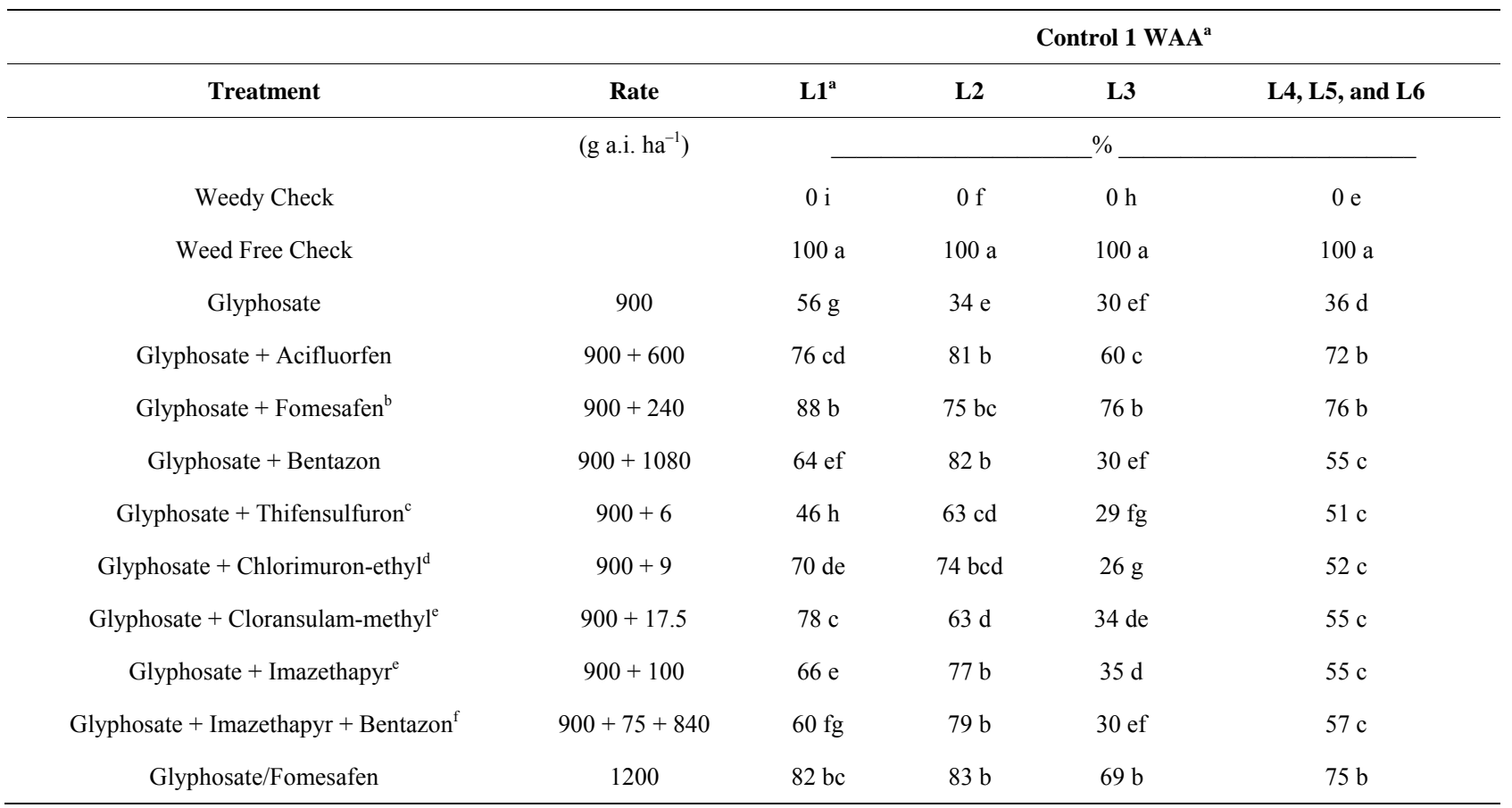

${ }^{\mathrm{a}}$ L1, LaSalle; L2, Windsor; L3, Amherstburg; L4, LaSalle; L5, Windsor; L6, LaSalle, WAA, weeks after herbicide application. ${ }^{\mathrm{b}}$ Included Turbocharge at $0.50 \%$ vol/vol. ${ }^{\circ}$ Included Agral 90 at $0.10 \%$ vol/vol plus UAN $28 \%$. ${ }^{d}$ Included Agral 90 at $0.20 \%$ vol/vol plus UAN $28 \%$. ${ }^{\circ}$ Included Agral 90 at $0.25 \%$ vol/vol plus UAN 28\%. Included UAN 28\%. ${ }^{\mathrm{a}-\mathrm{i}}$ Means followed by the same letter are not significantly different according to Fisher's Protected LSD at P $<0.05$. 
Table 3. Percent control of glyphosate resistant giant ragweed 2 WAA with herbicides applied post emergence.

\begin{tabular}{|c|c|c|c|c|c|}
\hline \multirow[b]{2}{*}{ Treatment } & \multirow[b]{2}{*}{ Rate } & \multicolumn{4}{|c|}{ Control 2 WAA $^{\mathrm{a}}$} \\
\hline & & $L 1$ and $L 2^{a}$ & L3 & $\mathbf{L 4}$ & L5, and L6 \\
\hline & $\left(\mathrm{g}\right.$ a.i. $\left.\mathrm{ha}^{-1}\right)$ & \multicolumn{4}{|c|}{$\%$} \\
\hline Weedy Check & & $0 \mathrm{~d}$ & $0 \mathrm{~h}$ & $0 \mathrm{~h}$ & $0 \mathrm{~g}$ \\
\hline Weed Free Check & & $100 \mathrm{a}$ & $100 \mathrm{a}$ & $100 \mathrm{a}$ & $100 \mathrm{a}$ \\
\hline Glyphosate & 900 & $38 \mathrm{c}$ & $37 \mathrm{ef}$ & $32 \mathrm{~g}$ & $34 \mathrm{f}$ \\
\hline Glyphosate + Acifluorfen & $900+600$ & $72 \mathrm{~b}$ & $70 \mathrm{~b}$ & $52 \mathrm{f}$ & $68 \mathrm{~b}$ \\
\hline Glyphosate + Fomesafen $^{\mathrm{b}}$ & $900+240$ & $74 \mathrm{~b}$ & $65 \mathrm{~b}$ & $59 \mathrm{de}$ & 52 cde \\
\hline Glyphosate + Bentazon & $900+1080$ & $67 \mathrm{~b}$ & $31 \mathrm{~g}$ & $57 \mathrm{def}$ & 44 def \\
\hline Glyphosate + Thifensulfuron ${ }^{\mathrm{c}}$ & $900+6$ & $50 \mathrm{bc}$ & $34 \mathrm{fg}$ & 56 ef & $40 \mathrm{ef}$ \\
\hline Glyphosate + Chlorimuron-ethyl $^{\mathrm{d}}$ & $900+9$ & $70 \mathrm{~b}$ & $40 \mathrm{e}$ & $61 \mathrm{cde}$ & 50 cde \\
\hline Glyphosate + Cloransulam-methyl $^{\mathrm{e}}$ & $900+17.5$ & $75 \mathrm{~b}$ & $62 \mathrm{~b}$ & $66 \mathrm{bc}$ & $56 \mathrm{bcd}$ \\
\hline 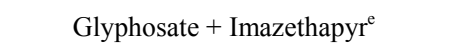 & $900+100$ & $76 \mathrm{~b}$ & $47 \mathrm{c}$ & $66 \mathrm{bc}$ & $63 \mathrm{bc}$ \\
\hline Glyphosate + Imazethapyr + Bentazon ${ }^{f}$ & $900+75+840$ & $75 \mathrm{~b}$ & $41 \mathrm{de}$ & $69 \mathrm{~b}$ & 53 bcde \\
\hline Glyphosate/Fomesafen & 1200 & $72 \mathrm{~b}$ & $46 \mathrm{~cd}$ & $62 \mathrm{bcd}$ & $65 \mathrm{bc}$ \\
\hline
\end{tabular}

${ }^{\mathrm{a}}$ L1, LaSalle; L2, Windsor; L3, Amherstburg; L4, LaSalle; L5, Windsor; L6, LaSalle, WAA, weeks after herbicide application. ${ }^{\mathrm{b}}$ Included Turbocharge at 0.50\% vol/vol. ${ }^{\mathrm{c}}$ Included Agral 90 at $0.10 \% \mathrm{vol} / \mathrm{vol}$ plus UAN $28 \%$. ${ }^{\mathrm{d}}$ Included Agral 90 at $0.20 \% \mathrm{vol} / \mathrm{vol}$ plus UAN $28 \%$. Included Agral 90 at $0.25 \%$ vol/vol plus UAN $28 \%$. Included UAN $28 \%$. ${ }^{\mathrm{a}-\mathrm{h}}$ Means followed by the same letter are not significantly different according to Fisher's Protected LSD at P $<0.05$.

Table 4. Percent control of glyphosate resistant giant ragweed 4 WAA with herbicides applied post emergence.

\begin{tabular}{|c|c|c|c|}
\hline \multirow[b]{2}{*}{ Treatment } & \multirow[b]{2}{*}{ Rate } & \multicolumn{2}{|c|}{ Control 4 WAA $^{a}$} \\
\hline & & $\mathrm{L} 1$ and $L 2^{\mathrm{a}}$ & $\mathrm{L3}, \mathrm{L} 4, \mathrm{~L} 5$ and $\mathrm{L6}$ \\
\hline & $\left(\mathrm{g}\right.$ a.i. $\left.\mathrm{ha}^{-1}\right)$ & & \\
\hline Weedy Check & & $0 \mathrm{e}$ & $0 \mathrm{~g}$ \\
\hline Weed Free Check & & $100 \mathrm{a}$ & $100 \mathrm{a}$ \\
\hline Glyphosate & 900 & $32 \mathrm{~d}$ & $23 \mathrm{f}$ \\
\hline Glyphosate + Acifluorfen & $900+600$ & $65 \mathrm{bcd}$ & 35 de \\
\hline Glyphosate + Fomesafen ${ }^{\mathrm{b}}$ & $900+240$ & $63 \mathrm{bcd}$ & $28 \mathrm{ef}$ \\
\hline Glyphosate + Bentazon & $900+1080$ & $60 \mathrm{bcd}$ & $24 \mathrm{f}$ \\
\hline Glyphosate + Thifensulfuron $^{\mathrm{c}}$ & $900+6$ & $44 \mathrm{~cd}$ & $25 \mathrm{f}$ \\
\hline 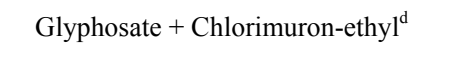 & $900+9$ & $73 \mathrm{bc}$ & 29 def \\
\hline Glyphosate + Cloransulam-methyl $^{\mathrm{e}}$ & $900+17.5$ & $74 \mathrm{bc}$ & $56 \mathrm{~b}$ \\
\hline 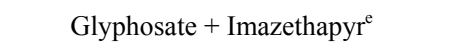 & $900+100$ & $82 \mathrm{~b}$ & $46 \mathrm{bc}$ \\
\hline Glyphosate + Imazethapyr + Bentazon $^{\mathrm{f}}$ & $900+75+840$ & $71 \mathrm{bc}$ & $34 \mathrm{de}$ \\
\hline Glyphosate/Fomesafen & 1200 & $69 \mathrm{bc}$ & $37 \mathrm{~cd}$ \\
\hline
\end{tabular}

${ }^{\mathrm{a}} \mathrm{L} 1$, LaSalle; L2, Windsor; L3, Amherstburg; L4, LaSalle; L5, Windsor; L6, LaSalle, WAA, weeks after herbicide application. ${ }^{\mathrm{b}}$ Included Turbocharge at $0.50 \%$ vol/vol. ${ }^{\mathrm{C}}$ Included Agral 90 at $0.10 \% \mathrm{vol} / \mathrm{vol}$ plus UAN $28 \%$. ${ }^{\mathrm{d}}$ Included Agral 90 at $0.20 \% \mathrm{vol} / \mathrm{vol}$ plus UAN $28 \%$. Included Agral 90 at $0.25 \%$ vol/vol plus UAN $28 \%$. Included UAN $28 \%{ }^{\mathrm{a}-\mathrm{g}}$ Means followed by the same letter are not significantly different according to Fisher's Protected LSD at P $<0.05$. 
cially active on this species with $18 \mathrm{~g}$ a.i. $\mathrm{ha}^{-1}$ providing $98 \%$ to $99 \%$ control of 12 to $15 \mathrm{~cm}$ glyphosate-resistant giant ragweed [16]. Glyphosate plus acifluorfen provided $35 \%$ to $65 \%$ control and was equivalent to glyphosate applied alone at L1 and L2. This is in contrast to the findings of Norsworthy et al. [16] who reported $76 \%$ to $87 \%$ control of glyphosate resistant giant ragweed with acifluorfen applied at $420 \mathrm{~g}$ a.i ha ${ }^{-1}$. Similarly applying fomesafen with glyphosate either as a tank mix or a premix gave only 69\% control (Table 4). Similar results were found with bentazon mixed with glyphosate. Glyphosate/ fomesafen, glyphosate plus chlorimuron-ethyl or imazethapyr plus bentazon provided up to $69 \%, 73 \%$ and $69 \%$ control, respectively (Table 4). Glyphosate plus fomesafen, bentazon and thifensulfuron provided less than $65 \%$ control and were equivalent to glyphosate applied alone across all locations. This is in contrast to the findings of Norsworthy et al. [16] who reported $100 \%$ control of glyphosate resistant giant ragweed with fomesafen applied alone at $263 \mathrm{~g}$ a.i. $\mathrm{ha}^{-1}$ or bentazon applied alone at $840 \mathrm{~g}$ a.i. ha ${ }^{-1}$.

At 8 WAA data could be combined into groups L1 and L2 and L4, L5 and L6 while L3 was analyzed separately (Table 5). Control was generally higher with all herbicides evaluated for group L1 and L2 compared to L3 and L4, L5 and L6 and may be due to higher levels of rainfall in 2011. The average rainfall for the months of May and
June 2011 were $179.4 \mathrm{~mm}$ and $83.4 \mathrm{~mm}$, respectively for Windsor Ontario [17]. The average rainfall for the months of May and June 2012 were $88.6 \mathrm{~mm}$ and $42.2 \mathrm{~mm}$, respectively for Windsor, Ontario [17]. Control may have also been higher in 2011 due to a higher proportion of resistant biotypes at sites L3 and L4, L5 and L6. Glyphosate provided $3 \%$ to $19 \%$ control. Glyphosate plus cloransulam-methyl was the most effective post emergence treatment providing $26 \%$ to $70 \%$ control. This is in contrast to the findings of Vink et al. [13] who reported $80 \%$ to $81 \%$ control with glyphosate plus cloransulammethyl applied at $900 \mathrm{~g}$ a.e. $\mathrm{ha}^{-1}+17.5 \mathrm{~g}$ a.i. $\mathrm{ha}^{-1}$. Glyphosate/fomesafen, glyphosate plus acifluorfen, chlorimuron-ethyl, or imazethapyr provided up to $45 \%, 38 \%$, $53 \%$ and $60 \%$ control, respectively. Glyphosate plus fomesafen, bentazon, thifensulfuron or imazethapyr plus bentazon were equivalent to glyphosate applied alone.

For giant ragweed shoot dry weight all data were combined and analyzed (Table 6). Glyphosate alone and glyphosate plus bentazon reduced giant ragweed shoot dry weight by $24 \%$ and $27 \%$ respectively and were equivalent to the weedy control. Glyphosate plus cloransulammethyl reduced giant ragweed shoot dry weight by $64 \%$. This is in contrast to Vink et al. [13] who reported a 98\% reduction in giant ragweed shoot dry weight with glyphosate plus cloransulam-methyl applied at $900 \mathrm{~g}$ a.e. $\mathrm{ha}^{-1}+17.5 \mathrm{~g}$ a.i. ha ${ }^{-1}$. Glyphosate plus fomesafen or

Table 5. Percent control of glyphosate resistant giant ragweed 8WAA with herbicides applied post emergence.

\begin{tabular}{|c|c|c|c|c|}
\hline \multirow[b]{2}{*}{ Treatment } & \multirow[b]{2}{*}{ Rate } & \multicolumn{3}{|c|}{ Control 8 WAA $^{a}$} \\
\hline & & $L 1$ and $L 2^{a}$ & L3 & L4, L5 and L6 \\
\hline & $\left(\mathrm{g}\right.$ a.i. $\left.\mathrm{ha}^{-1}\right)$ & \multicolumn{3}{|c|}{$\%$} \\
\hline Weedy Check & & $0 \mathrm{f}$ & $0 \mathrm{f}$ & $0 \mathrm{e}$ \\
\hline Weed Free Check & & $100 \mathrm{a}$ & $100 \mathrm{a}$ & $100 \mathrm{a}$ \\
\hline Glyphosate & 900 & $19 \mathrm{e}$ & $3 \mathrm{e}$ & $11 \mathrm{~d}$ \\
\hline Glyphosate + Acifluorfen & $900+600$ & 38 cde & $11 \mathrm{~cd}$ & $14 \mathrm{~cd}$ \\
\hline Glyphosate + Fomesafen $^{\mathrm{b}}$ & $900+240$ & 41 bcde & $7 \mathrm{cde}$ & $12 \mathrm{~cd}$ \\
\hline Glyphosate + Bentazon & $900+1080$ & 35 cde & $5 \mathrm{de}$ & $12 \mathrm{~cd}$ \\
\hline Glyphosate + Thifensulfuron $^{\mathrm{c}}$ & $900+6$ & $29 \mathrm{de}$ & $5 \mathrm{de}$ & $10 \mathrm{~d}$ \\
\hline Glyphosate + Chlorimuron-ethyl ${ }^{\mathrm{d}}$ & $900+9$ & $53 \mathrm{bcd}$ & 7 cde & $12 \mathrm{~cd}$ \\
\hline Glyphosate + Cloransulam-methyl ${ }^{\mathrm{e}}$ & $900+17.5$ & $70 \mathrm{ab}$ & $55 \mathrm{~b}$ & $26 \mathrm{~b}$ \\
\hline Glyphosate + Imazethapyr ${ }^{\mathrm{e}}$ & $900+100$ & $60 \mathrm{bc}$ & $13 \mathrm{c}$ & $18 \mathrm{bc}$ \\
\hline Glyphosate + Imazethapyr + Bentazon ${ }^{\mathrm{f}}$ & $900+75+840$ & 40 bcde & $4 \mathrm{e}$ & $13 \mathrm{~cd}$ \\
\hline Glyphosate/Fomesafen & 1200 & $45 \mathrm{bcd}$ & $5 \mathrm{e}$ & $14 \mathrm{~cd}$ \\
\hline
\end{tabular}

${ }^{\mathrm{a}}$ L1, LaSalle; L2, Windsor; L3, Amherstburg; L4, LaSalle; L5, Windsor; L6, LaSalle, WAA, weeks after herbicide application. ${ }^{\mathrm{b}}$ Included Turbocharge at 0.50\%

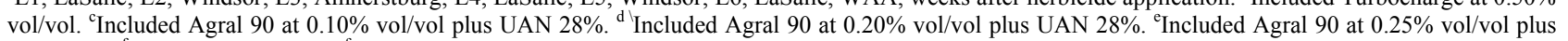
UAN 28\%. ${ }^{\mathrm{f}}$ Included UAN 28\%. ${ }^{\mathrm{a}-\mathrm{f}}$ Means followed by the same letter are not significantly different according to Fisher's Protected LSD at P $<0.05$. 
Table 6. Glyphosate resistant giant ragweed shoot dry weight and soybean yield for herbicides applied post emergence.

\begin{tabular}{|c|c|c|c|c|c|}
\hline \multirow[b]{2}{*}{ Treatment } & \multirow[b]{2}{*}{ Rate } & \multicolumn{2}{|l|}{ Giant ragweed shoot dry weight } & \multicolumn{2}{|c|}{ Soybean yield ${ }^{a}$} \\
\hline & & All combined & $\mathrm{L} 1$ and $\mathrm{L2}^{\mathrm{a}}$ & $\mathbf{L 3}$ & L4, L5, and L6 \\
\hline & $\left(\mathrm{g}\right.$ a.i. $\left.\mathrm{ha}^{-1}\right)$ & $\left(\mathrm{g} \cdot \mathrm{m}^{-2}\right)$ & 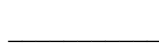 & $\left(t \cdot a^{-1}\right)$ & \\
\hline Weedy Check & & $43.1 \mathrm{e}$ & $0.65 \mathrm{c}$ & $0.20 \mathrm{c}$ & $0.26 \mathrm{~cd}$ \\
\hline Weed Free Check & & $0.0 \mathrm{a}$ & $2.68 \mathrm{a}$ & $4.03 \mathrm{a}$ & $1.90 \mathrm{a}$ \\
\hline Glyphosate & 900 & $32.9 \mathrm{de}$ & $1.10 \mathrm{bc}$ & $0.13 \mathrm{~cd}$ & $0.28 \mathrm{~cd}$ \\
\hline Glyphosate + Acifluorfen & $900+600$ & $22.6 \mathrm{bcd}$ & $1.57 \mathrm{~b}$ & $0.08 \mathrm{~cd}$ & $0.30 \mathrm{~cd}$ \\
\hline Glyphosate + Fomesafen ${ }^{\mathrm{b}}$ & $900+240$ & $20.2 \mathrm{bc}$ & $1.31 \mathrm{bc}$ & $0.16 \mathrm{~cd}$ & $0.33 \mathrm{c}$ \\
\hline Glyphosate + Bentazon & $900+1080$ & $31.4 \mathrm{de}$ & $1.37 \mathrm{~b}$ & $0.09 \mathrm{~cd}$ & $0.18 \mathrm{~d}$ \\
\hline Glyphosate + Thifensulfuron ${ }^{c}$ & $900+6$ & $28.9 \mathrm{~cd}$ & $1.17 \mathrm{bc}$ & $0.07 \mathrm{~cd}$ & $0.27 \mathrm{~cd}$ \\
\hline Glyphosate + Chlorimuron-ethyl ${ }^{\mathrm{d}}$ & $900+9$ & $24.1 \mathrm{bcd}$ & $1.60 \mathrm{~b}$ & $0.07 \mathrm{~d}$ & $0.31 \mathrm{c}$ \\
\hline 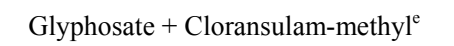 & $900+17.5$ & $15.7 \mathrm{~b}$ & $1.70 \mathrm{~b}$ & $0.45 \mathrm{~b}$ & $0.50 \mathrm{~b}$ \\
\hline Glyphosate + Imazethapyr $^{\mathrm{e}}$ & $900+100$ & $16.6 \mathrm{~b}$ & $1.63 \mathrm{~b}$ & $0.18 \mathrm{~cd}$ & $0.41 \mathrm{bc}$ \\
\hline Glyphosate + Imazethapyr + Bentazon ${ }^{\mathrm{f}}$ & $900+75+840$ & $23.0 \mathrm{bcd}$ & $1.02 \mathrm{bc}$ & $0.09 \mathrm{~cd}$ & $0.34 \mathrm{bc}$ \\
\hline Glyphosate/Fomesafen & 1200 & $25.9 \mathrm{~cd}$ & $1.26 \mathrm{bc}$ & $0.09 \mathrm{~cd}$ & $0.31 \mathrm{c}$ \\
\hline
\end{tabular}

${ }^{a}$ L1, LaSalle; L2, Windsor; L3, Amherstburg; L4, LaSalle; L5, Windsor; L6, LaSalle. ${ }^{b}$ Included Turbocharge at $0.50 \%$ vol/vol. ${ }^{\mathrm{c}}$ Included Agral 90 at $0.10 \%$ $\mathrm{vol} / \mathrm{vol}$ plus UAN $28 \%$. ${ }^{\mathrm{d}}$ Included Agral 90 at $0.20 \% \mathrm{vol} / \mathrm{vol}$ plus UAN $28 \%$. ${ }^{\mathrm{e}}$ Included Agral 90 at $0.25 \% \mathrm{vol} / \mathrm{vol}$ plus UAN $28 \%$. Included UAN $28 \%$, ${ }^{\mathrm{a}-\mathrm{e}}$ Means followed by the same letter are not significantly different according to Fisher's Protected LSD at $\mathrm{P}<0.05$.

imazethapyr reduced giant ragweed shoot dry weight by $53 \%$ and $61 \%$, respectively (Table 6). Glyphosate/fomesafen, glyphosate plus acifluorfen, thifensulfuron, chlorimuron-ethyl or imazethapyr plus bentazon reduced giant ragweed shoot dry weight by less than $50 \%$ (Table 6).

Soybean yield data L1 and L2 and L4, L5 and L6 could be combined while L3 was analyzed separately (Table 6). Giant ragweed interference caused a reduction in soybean yield of $76 \%$ to $95 \%$ across all sites. Baysinger and Sims [18] reported a $92 \%$ yield loss in soybean due to giant ragweed interference. Giant ragweed interference with glyphosate alone caused a 59 to $97 \%$ reduction in soybean yield and was equivalent to the weedy control across all sites. Giant ragweed interference where glyphosate plus cloransulam-methyl was applied reduced soybean yield by $37 \%$ to $89 \%$. In a previous study, there was no reduction in soybean yield with cloransulam-methyl applied at $17.5 \mathrm{~g}$ a.i. $\mathrm{ha}^{-1}$ and there was a $32 \%$ to $40 \%$ reduction in soybean yield with glyphosate plus cloransulam-methyl applied at $900 \mathrm{~g}$ a.e. $\mathrm{h}^{-1}$ $+17.5 \mathrm{~g}$ a.i. $\mathrm{ha}^{-1}$ [13]. Glyphosate plus acifluorfen, bentazon, chlorimuron-ethyl or imazethapyr reduced soybean yield by $41 \%$ to $98 \%, 49 \%$ to $98 \%, 40 \%$ to $98 \%, 39 \%$ to $96 \%$, respectively. This is similar to the findings of a previous study that reported a reduction in soybean yield equivalent to the weedy control when glyphosate plus clorimuron-ethyl, fomesafen and imazethapyr plus ben- tazon was applied [13]. Giant ragweed interference with glyphosate/fomesafen, glyphosate plus fomesafen, thifensulfuron, or imazethapyr plus bentazon reduced soybean yield by up to $98 \%, 96 \%, 98 \%$ and $98 \%$, respectively and were equivalent to the weedy control. The reduction in yields with these herbicides is consistent with the control ratings and giant ragweed shoot dry weight.

\subsection{2,4-D Dose Response}

Soybean injury was observed at L4 1 WAE (weeks after emergence) with 2,4-D at rates of $1000 \mathrm{~g}$ a.e. $\mathrm{ha}^{-1}$ or greater. Soybean injury (delayed emergence) of $10 \%$ and $50 \%$ was observed at 1000 and 2000 g a.e. ha ${ }^{-1}$, respectively (data not shown). Soybean injury was not observed at rates of $500 \mathrm{~g}$ a.e. $\mathrm{ha}^{-1}$ or less. Accentuated soybean injury at this site may be due to higher rainfall before and after application in 2011. The average rainfall for the month of May 2011 at this location was $179.4 \mathrm{~mm}$ [17]. In contrast the average rainfall for the month of May 2012 at this location was $88.6 \mathrm{~mm}$ [17].

Generally there was a high dose required for $80 \%$ and $95 \%$ control compared to the dose required for $50 \%$ control (Table 7). This may be due to the greater chance of error as the experiment was not designed specifically for evaluating the $\mathrm{ED}_{80}$ and $\mathrm{ED}_{95}$ [15]. The 2,4-D dose needed to achieve $50 \%$ control 1 WAA was 19 to $57 \mathrm{~g}$ 
Table 7. 2,4-D dose response for glyphosate-resistant giant ragweed control 1, 2, 4, and 8 WAA, shoot dry weight and soybean yield ${ }^{\mathrm{a}}$.

\begin{tabular}{|c|c|c|c|c|c|c|c|c|}
\hline \multirow[b]{2}{*}{ Dose Response } & \multirow[b]{2}{*}{ Location $^{\mathrm{d}}$} & \multicolumn{4}{|c|}{ Regression parameters $^{\mathrm{b}}( \pm \mathrm{SE})$} & \multicolumn{3}{|c|}{ 2,4-D Dose (g a.e. ha $\left.^{-1}\right)^{\mathrm{c}}$} \\
\hline & & D & C & B & $\mathbf{I}_{50}$ & $\mathbf{E D}_{50}$ & $\mathbf{E D}_{80}$ & $\mathbf{E D}_{95}$ \\
\hline \multicolumn{9}{|l|}{ Giant ragweed control } \\
\hline \multirow[t]{3}{*}{$1 \mathrm{WAA}$} & $\mathrm{L} 1, \mathrm{~L} 2$ & $88.8(0.0)$ & $30.6(0.4)$ & $3.0(0.8)$ & $72.3(7.5)$ & 57.4 & 128.5 & - \\
\hline & $\mathrm{L} 3, \mathrm{~L} 5$ & $84.8(0.0)$ & $0.0(0.0)$ & $2.4(0.2)$ & $16.6(1.1)$ & 19.3 & 53.6 & - \\
\hline & $\mathrm{L} 4$ & $89.6(0.1)$ & $0.0(0.0)$ & $1.1(0.2)$ & $24.5(2.4)$ & 30.3 & 168.4 & - \\
\hline \multirow[t]{3}{*}{2 WAA } & $\mathrm{L} 1, \mathrm{~L} 2$ & $91.7(0.0)$ & $24.5(0.2)$ & $3.7(0.8)$ & $97.3(7.7)$ & 85.2 & 148.2 & - \\
\hline & L3, L5 & $92.8(0.0)$ & $0.0(0.0)$ & $0.9(0.1)$ & $31.1(2.0)$ & 37.0 & 238.3 & - \\
\hline & L4 & $91.0(1.4)$ & $0.0(0.0)$ & $1.4(0.1)$ & $40.2(2.1)$ & 46.3 & 165.9 & - \\
\hline \multirow[t]{4}{*}{4 WAA } & L1 & $100.0(1.3)$ & $25.0(9.4)$ & $1.0(0.5)$ & $118.6(65.8)$ & 59.3 & 326.2 & 1660.4 \\
\hline & $\mathrm{L} 2$ & $95.7(1.3)$ & $14.4(-0.4)$ & $6.5(2.7)$ & $98.3(11.2)$ & 94.6 & 122.5 & 204 \\
\hline & L4 & $100(0.1)$ & $9.5(1.4)$ & $1.6(0.2)$ & $84.9(12.5)$ & 74.4 & 186.6 & 500.6 \\
\hline & L3, L5 & $100(0.1)$ & $0.0(0.0)$ & $1.0(0.1)$ & $68.2(12.5)$ & 68.2 & 272.8 & 1295.8 \\
\hline \multirow[t]{3}{*}{8 WAA } & L1, L2 & $99.2(0.2)$ & $4.5(1.1)$ & $2.4(0.6)$ & $115.2(13.7)$ & 111.5 & 203.8 & 414.0 \\
\hline & L3, L5 & $100.0(0.1)$ & $1.5(2.0)$ & $1.5(0.3)$ & $95.9(14.7)$ & 94.0 & 238.6 & 675.6 \\
\hline & L4 & $100.0(0.1)$ & $0.0(0.0)$ & $1.1(0.1)$ & $84.4(5.8)$ & 84.4 & 297.6 & 1227.0 \\
\hline Giant ragweed shoot dry weight & All combined & $97.0(0.2)$ & $0.0(0.0)$ & $1.9(0.2)$ & $137.3(11.7)$ & 141.8 & 310.2 & 1047.5 \\
\hline Soybean yield & All combined & $100.0(0.0)$ & $20.0(4.6)$ & $1.5(0.3)$ & $190.9(28.9)$ & 135.8 & 397.1 & 1161.1 \\
\hline
\end{tabular}

abbreviations: WAA, weeks after application. ${ }^{\mathrm{b}}$ Regression parameters: D, upper limit; $\mathrm{C}$, lower limit; $\mathrm{B}$, slope at $\mathrm{I}_{50} ; \mathrm{I}_{50}$, rate needed for $50 \%$ response. ${ }^{\mathrm{c}} \mathrm{ED} \mathrm{D}_{50}$, $\mathrm{ED}_{80}$ and $\mathrm{ED}_{95}$ : Rates needed to achieve $50 \%, 80 \%$ and $95 \%$ control of giant ragweed compared to weed-free control. Rates needed to achieve $50 \%$, $80 \%$ and $95 \%$ soybean yield compared to the weed-free control. Rates needed to achieve $50 \%, 80 \%$ and $95 \%$ reduction in giant ragweed shoot dry weight compared to the weedy control. ${ }^{\mathrm{d}}$ Location: L1, LaSalle; L2, Windsor; L3, Amherstburg; L4, LaSalle; L5, Windsor.

a.e. $\mathrm{ha}^{-1}$. To achieve $80 \%$ control 1 WAA, the $2,4-\mathrm{D}$ dose required was 53 to $168 \mathrm{~g}$ a.e. ha ${ }^{-1}$. At 2 WAA, the dose needed to obtain $50 \%$ control was 37 to $85 \mathrm{~g}^{\text {a.e. }} \mathrm{ha}^{-1}$ while the dose needed to achieve $80 \%$ control was 148 to $238 \mathrm{~g}$ a.e. $\mathrm{ha}^{-1}$.

At 4 WAA, L3 and L5 could be combined and L1, L2 and L4 were analyzed separately (Table 7). At L1 and L3 and L5, 59 and $68 \mathrm{~g}$ a.e. $\mathrm{ha}^{-1}$ of 2,4-D was needed to achieve $50 \%$ control and 1660 and 1296 g a.e. ha ${ }^{-1}$ was needed to achieve $95 \%$ control, respectively. In contrast at L2 and L4, 95 and $74 \mathrm{~g}$ a.e. $\mathrm{ha}^{-1}$ was needed to achieve $50 \%$ control and 204 and $501 \mathrm{~g}$ a.e. $\mathrm{ha}^{-1}$ was needed to achieve $95 \%$ control, respectively. This is similar to the findings of Vink et al. [14] who reported $97 \%$ to $98 \%$ control of glyphosate-resistant giant ragweed with glyphosate plus 2,4-D ester applied at $900 \mathrm{~g}$ a.e. $\mathrm{ha}^{-1}+500$ g a.e. $\mathrm{ha}^{-1} 4$ WAA.

At 8 WAA L1 and L2 and L3 and L5 could be combined and L4 was analyzed separately (Table 7). At L1 and L2, $414 \mathrm{~g}$ a.e. $\mathrm{ha}^{-1}$ of 2,4-D was needed to achieve 95\% control. At L3 and L5 $94 \mathrm{~g}$ a.e. $\mathrm{ha}^{-1}$ of 2,4-D was needed to achieve $50 \%$ control and $676 \mathrm{~g}$ a.e. ha ${ }^{-1}$ was needed to achieve 95\% control. In contrast, at L4 $1227 \mathrm{~g}$ a.e. $\mathrm{ha}^{-1}$ of $2,4-\mathrm{D}$ was needed to achieve $95 \%$ control.

For giant ragweed shoot dry weight all data could be combined (Table 7). The 2,4-D dose required to reduce giant ragweed shoot dry weight by 50, 80 and $95 \%$ was 142,310 and $1048 \mathrm{~g}$ a.e. $\mathrm{ha}^{-1}$, respectively, which was generally higher than the dose required for control 4 WAA.

For soybean yield all data could be combined (Table 7). The dose of 2,4-D required for 50,80 and $95 \%$ of the soybean yield in the weed free control was 136, 397 and $1161 \mathrm{~g}$ a.e. $\mathrm{ha}^{-1}$, respectively which closely follows the rate of 2,4-D required to reduce giant ragweed shoot dry weight by 50,80 and $95 \%$. These data confirm that weed shoot dry weight is a good indicator of weed interference.

\section{Conclusion}

In summary, the postemergence broadleaf herbicides registered for use in Ontario provided variable control of glyphosate resistant giant ragweed across all sites. In general, the postemergence broadleaf herbicides did not 
provide commercially acceptable control of glyphosate resistant giant ragweed. Glyphosate plus cloransulammethyl was the best of the herbicides evaluated; however, it did not provide acceptable control. The reduced control observed in this study may be due to multiple resistant giant ragweed. For the 2,4-D dose response experiment, 414 to $1227 \mathrm{~g}$ a.e. $\mathrm{ha}^{-1}$ of 2,4-D plus glyphosate applied at $900 \mathrm{~g}$ a.e. $\mathrm{ha}^{-1}$ was needed to achieve $95 \%$ control. This research concludes that growers must control glyphosate resistant giant ragweed before soybean emergence since none of the postemergence broadleaf herbicides registered in Ontario provides commercially acceptable control of glyphosate resistant giant ragweed. In addition, the lowest effective rate of 2,4-D applied preplant for the control of glyphosate resistant giant ragweed is $500 \mathrm{~g}$ a.e. $\mathrm{ha}^{-1}$. Future research should study other herbicide tank mixes coupled with alternative management strategies such as tillage and crop rotation.

\section{Acknowledgements}

The authors acknowledge Chris Kramer for his expertise and technical assistance in these studies. Funding for this project was provided in part by Monsanto Canada Inc., the Grain Farmers of Ontario and the Agricultural Adaptation Council through the Canadian Agricultural Adaptation Program.

\section{REFERENCES}

[1] J. E. Franz, M. K. Mao and J. A. Sikorski, "Glyphosate: A Unique Global Herbicide,” American Chemical Society, Washington, 1997.

[2] G. M. Dill, R. D. Sammons, P. C. C. Feng, F. Kohn, K. Kretzmer, A. Mehrsheikh, M. Bleeke, J. L. Honegger, D. Farmer, D. Wright and E. A. Haupfear, "Glyphosate: Discovery, Development, Applications, and Properties," In: V. K. Nandula, Ed., Glyphosate Resistance in Crops and Weeds: History, Development, and Management, John Wiley and Sons, Inc., Hoboken, 2010, pp. 1-33. doi:10.1002/9780470634394.ch1

[3] G. M. Dill, C. A. CaJacob and S. R. Padgette, "Glyphosate Resistant Crops: Adoption, Use and Future Considerations," Pest Management Science, Vol. 64, No. 4, 2008, pp. 326-331. doi:10.1002/ps.1501

[4] M. M., Vila-Aiub, R. A. Vidal, M. C. Balbi, P. E. Gundel, F. Trucco and C. M. Ghersa, "Glyphosate-Resistant Weeds of South American Cropping Systems: An Overview," Pest Management Science, Vol. 64, No. 4, 2008, pp. 366371. doi: $10.1002 / \mathrm{ps} .1488$

[5] M. D. K. Owen, "Weed Species Shifts in GlyphosateResistant Crops," Pest Management Science, Vol. 64, No. 4, 2008, pp. 377-387. doi:10.1002/ps.1539
[6] S. B. Powles, D. F. Lorraine-Colwill, J. J. Dellow and C. Preston, "Evolved Resistance to Glyphosate in Rigid Ryegrass (Lolium rigidum) in Australia," Weed Science, Vol. 46, No. 5, 1998, pp. 604-607.

[7] I. Heap, "International Survey of Herbicide Resistant Weeds," 2012. http://www.weedscience.org/In.asp

[8] I. J. Bassett and C. W. Crompton, "The Biology of Canadian Weeds. 55. Ambrosia trifida L.," Canadian Journal of Plant Science, Vol. 62, No. 4, 1982, pp. 1003-1010. doi:10.4141/cjps82-148

[9] Ontario Ministry of Agriculture, Food and Rural Affairs (OMAFRA), "Ontario Weeds," Publication 505, Guelph, 2001, pp. 214-215.

[10] S. K. Harrison, E. E. Regnier, J. T. Schmoll and J. E. Webb, "Competition and Fecundity of Giant Ragweed in Corn," Weed Science, Vol. 49, No. 2, 2001, pp. 224-229. doi:10.1614/0043-1745(2001)049[0224:CAFOGR]2.0.C $\underline{\mathrm{O} ; 2}$

[11] B. J. Schutte, E. E. Regnier and S. K. Harrison, "The Association between Seed Size and Seed Longevity among Maternal Families in Ambrosia trifida L. Populations," Seed Science Research, Vol. 18, No. 4, 2008, pp. 201-211. doi:10.1017/S0960258508082974

[12] J. P. Vink, N. Soltani, D. E. Robinson, F. J. Tardif, M. B. Lawton and P. H. Sikkema, "Occurrence and Distribution of Glyphosate-Resistant Giant Ragweed (Ambrosia trifida L.) in Southwestern Ontario," Canadian Journal of Plant Science, Vol. 92, No. 3, 2012, pp. 533-539. doi:10.4141/cjps2011-249

[13] J. P. Vink, N. Soltani, D. E. Robinson, F. J. Tardif, M. B. Lawton and P. H. Sikkema, "Glyphosate-Resistant Giant Ragweed (Ambrosia trifida L.) in Ontario: Dose Response and Control with Postemergence Herbicides," American Journal of Plant Sciences, Vol. 3, No. 5, 2012, pp. 608-617. doi:10.4236/ajps.2012.35074

[14] J. P. Vink, N. Soltani, D. E. Robinson, F. J. Tardif, M. B. Lawton and P. H. Sikkema, "Glyphosate-Resistant Giant Ragweed (Ambrosia trifida L.) Control with Preplant Herbicides in Soybean (Glycine max L.)," Canadian Journal of Plant Science, Vol. 92, No. 5, 2012, pp. 913922. doi:10.4141/cjps2012-025

[15] S. S. Seefeldt, J. E. Jensen and E. P. Fuerst, "Log-Logistic Analysis of Herbicide Dose-Response Relationships," Weed Technology, Vol. 9, No. 2, 1995, pp. 218-227.

[16] J. K. Norsworthy, D. Riar, P. Jha and R. C. Scott, "Confirmation, Control, and Physiology of Glyphosate-Resistant Giant Ragweed (Ambrosia trifida) in Arkansas," Weed Technology, Vol. 25, No. 3, 2011, pp. 430-435. doi:10.1614/WT-D-10-00155.1

[17] Environment Canada, "Climate Normals," 2013. http://www.climate.weatheroffice.gc.ca/climateData/daily data e.html

[18] J. A. Baysinger and B. D. Sims, "Giant Ragweed (Ambrosia trifida) Control in Soybean (Glycine max)," Weed Technology, Vol. 6, No. 1, 1992, pp. 13-18. 